\title{
Assessment of Public-Private Partnership in Technical Colleges in Nigeria: A Case of Lagos State
}

\author{
Sulaimon Adewale ${ }^{1}$
}

\begin{abstract}
This study examined the state of Public-Private Partnerships in technical colleges in Nigeria, using Lagos state as a case study. Four research questions guided the study. It was a cross-sectional descriptive study adopted a mixed method research design. The population of the study comprised of all the 350 academic staff in the five government technical colleges in Lagos state. Purposive sampling technique was used to sample 50 teachers. Questionnaire and semi-structured interview were used to collect data. Quantitative data were analyzed using descriptive statistics to answer research questions one, two and three while descriptive narratives were used to analyse interview responses. Cronbach alpha technique was used to determine the reliability of the questionnaire and a coefficient of 0.69 was obtained.The finding indicated that public-private partnerships existed partially as a strategy for funding technical colleges in Lagos for skills acquisition. Based on the findings, it was recommended among others that colleges may set up a partnership committee to liaise with industries; government should do away with making of obnoxious policies that discourage private organisations; and National Board on Technical Education may make business grant cum start-up loan available for the graduates of technical colleges.
\end{abstract}

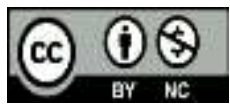

Keywords: public-private partnership, skills acquisition, technical college, TVET, funding

\section{Introduction}

The developed nations did not just achieved a great feat by mere hoping or putting down policies on pages of papers, but by bringing together the important and forces to actualize the dream of each of the sectors of their nations. Sharing similar attributes with many developed countries Lagos is the most populous state in Nigeria (Internet geography, 2016). Despite the relocation of the federal capital territory of Nigeria to Abuja in the year 1991, Lagos remains important to the social-economic and political development of Nigeria. According to (Internet geography, 2016) 80\% of industries in Nigeria are located in Lagos state and it remains the financial center of West Africa. The state therefore invests in Technical and Vocational Education and Training (TVET) by

\footnotetext{
${ }^{1}$ Department of Educational Management, Faculty of Education, University of Ilorin, Nigeria Email: sulady.sa@gmail.com
} 
establishing five technical colleges in the five divisions of the state for the purpose of human capital development.

However, TVET programmes would have been a catalyst to socioeconomic fortune in Nigeria but the sector is bedeviled by many challenges, which have made its goals mere mirage (Aina \& Akintunde, 2013; Igberadja, 2014; Olabiyi, Okafor, \& Bamidele, 2014). Until the problems are solved, the citizens will not feel the impacts of technical education. Suriana (2012) and Igberadja (2014) have identified as the bedrock upon which other problems of TVET rest inadequate funding. This has further caused these skills acquisition institution to train students with obsolete and non-relevant facilities (Ijaiya \& Adewale , 2017) owing to inability to acquire new and relevant ones. Most of the available training infrastructure is not $21^{\text {st }}$ century compliant while the available ones are either not in good condition for use or obsolete. Consequent upon this imbroglio is mass production of poorly skilled graduates for labour market equipped with irrelevant skills to employing industries.

Furthermore, the increase in unemployment rate in Nigeria from $23.1 \%$ in the year 2018 to $27.1 \%$ in year 2020 (NBS, 2020) could be blamed on lack of requisite skills among the youths of today, particularly those who have passed through secondary education level. This skills mismatch in Nigeria is blamed on poor communication of industrial need in terms of skills to training institutions. Japan International Cooperation Agency, JICA (2014) maintained that difficulty in grasping skill demand of industries is a great challenge to TVET. Hence, this lack of or insufficient information about the actual skills needed in the labour market must be addressed by both the college and the industries for students to become hot cakes to the employers.

In view of these skirmishes, the Nigerian Institute of Social and Economic Research, NISER,(2009) reported that the government, researchers and development partners have since fully engaged in finding a lasting solution to these problems. Among the consequences of this effort was the studies of Okpor and Hassan (2012) who suggested a number of solutions that if sincerely implemented would put TVET in good shape, particularly in the area of elimination of skills mismatch, infrastructural problem and funding of the training institutions. One of these noble solutions suggested is Public-Private Partnership (PPP). This requires a virile collaboration between the training colleges and industries for goals achievement. The partnership as a strategic solution according to Josh (2007) is critical to the development of high quality vocational education and training because it allows for regular communication between employers and technical vocational education and training providers to get a meaningful result that will benefit both parties. 


\subsection{Objectives of the Study}

The specific purposes of this study were to:

1. determine the type of private bodies mostly in partnership with technical colleges in Lagos state on students' skills acquisition.

2. determine the level of partnership in technical colleges in Lagos state.

3. determine the areas PPP is assisting in the acquisition of skills in technical colleges in Lagos state.

4. determine what propel the private organisations to enter into partnership with technical colleges.

\subsection{Research Questions}

The following research questions guided the study:

1. Which type of private bodies are mostly in partnership with technical colleges in Lagos state on students' skills acquisition?

2. What is the level of partnerships between technical colleges and private bodies in Lagos state?

3. What areas is PPP assisting in the acquisition of skills in technical colleges in Lagos state?

4. What propel the private organizations to enter into partnership with technical colleges?

\subsection{Significance of the Study}

The result of this study will help to sensitise the education ministries and the NBTE in Nigeria to organize reach out to private organisations on the role they can play via TVET to ameliorate unemployment in Nigeria.

The outcome of this study will alert the government to organize more leadership trainings for principals to improve their administrative competence and enhance teachers' performances, which will influence the attainment of TVET goals.

It is also believed that findings of this study will be of huge benefits to the operators of TVET colleges by equipping them with efficient and effective strategies suitable for the transformation of TVET, and timing of adoption of each of the strategies to facilitate the attainment of goals of establishing technical colleges.

The findings of this study will also add to the existing knowledge banks and help the educational stakeholders (government, educational planners, principals, teachers, parents and students) to comprehend the importance of efficient management of the limited available human and material resources to ensure a quality instead of a poor quantitative social demand approach to education particularly TVET in Nigeria. 


\section{Literature Review}

Public-Private Partnership is a nebulous concept that has been subjected numerous definitions. It is characterized by infrastructure or service funded in whole or part by private bodies (Ayonmike, Igberedja, Igberaharha, \& Okeke, 2014). It has been defined by Berezin (2018) and Dunbar (2013) as a voluntary alliance among various actors from different sectors, whereby they agree to work together to reach a common goal, or fulfill a specific need that involves shared risks, responsibilities and competencies. This could be because $21^{\text {st }}$ century has come with changes in workplace, industries and business environment due to technological advancement. It is therefore required a lot of human and material resources that can sufficiently be provided by synergy between public and private organisations. The changes according to Ezenwafor (2015) posed enormous challenges to individual workers, business managers, organisations and nations and require a repositioning of TVET to ensure that the skills acquired by students are relevant.

The fundamental objective of public-private partnership described by Olabiyi, Okafor, and Bamidele (2014) is to encourage the private sector to use its facility or capital and the capability to build projects on time and to budget for the welfare of technical and vocational institutions, without having to compromise its profit motive. The purpose of partnership is that none of the actors is in a zero sum game (McQuaid, 2000). This means that all the partners will gain from joining their resources together. Furthermore, brings in resources, such as information and expertise not available in an organisation. The use of public-private partnership in technical colleges in Nigeria is necessitated by the huge amount of money required to achieve its laudable goals. This is why Aina and Akintunde (2013) posited that government alone could not bear the burden of the cost of functional education in Nigeria; as such, private sector must be involved. In an ideal situation, education services and skills development ought to be a collective responsibility of government and non-government organisations, industries, philanthropists and the likes.

School (Public)-industry partnership is the cooperative relationship between schools and industies with agreement to share responsibily for achieving a specific goal of imparting skills in the students to develop the economy. Mbah, Obi, Ehimen, and Onyebuenyi (2018) defined it as the collaboration between formal education and industry to create enabling training environment for students to acquire on the job experiences, knowledge, skills and appropriate attitude to work. Furthermore, UNESCO (2002) maintained that when there is collaboration between industries and TVET institutions, students will benefit from early introduction to the world of work because of practical work 
experiences. This presupposes that technical colleges will be able to adapt their curricular to the needs of the labour market. Above all, students with the greatest potential for a future long-term contract will be identified at an early stage. The partnership is germane because it helps to deliver continuing education and training of the workforce, which can be through purely private initiatives or can leverage public institutions and schemes. Although, there are many modes of partnerships, this study is concerned with the form in which private sectors support educational sector through philanthropic activities and high-engagement venture.

Joynes, et al (2019) has rightly observed that $21^{\text {st }}$ century changes include redefinition cum reorganization of jobs, and relevant skills for performance based on the impact of technology and increased global competition affecting types of works and how they are done. Public-Private Partnerships for skills acquisition is any type of institutionalized collaboration between the public and the private sectors that aims to develop the skills of students, the workforce or the general public (OECD, 2013). This is necessitated because PPP demands that private sectors' resources and expertise be introduced to deliver public services (Maigida, 2014). PPP in Nigeria can help to define current skills needs, increase matching with skills supply, forecast future skills needs and revise skills production accordingly. In furtherance of this submission, Ezenwafor (2015) pinpointed that changes in the $21^{\text {st }}$ century demand that workers should possess new sets of skills and competencies than those they succeded in the past. Usen and Offiong (2016) confirmed that partnership in Nigeria will engender effective contribution to implementation of TVET programme meant for skill acquisition.

More importantly, skills available in the workforce and skills demanded by employers do not exactly match and skills gap comes at a cost for the economy. Therefore, Public-Private consultations on skills needed may help solve part of the mismatch issue by confronting government initiatives with feedback from enterprises and by putting enterprises in charge of some of the skills policies they benefit from (OECD, 2013). Similarly, stakeholders' commitment to public-private partnerships would be accomplished through focusing on micro, small and medium-sized operations, involving community leaderships like community development associations, town unions and paramount chiefs (Okpor \& Hassan, 2012).

In spite of all its benefits, PPP is not free from obstacles. It obstacles according to Ayonmike, Igberedja, Igberaharha and Okeke (2014) range from obnoxious government policies that make industries unwilling to participate, political instability, negative attitude of government officials towards local inventions and researches, poor management of fund and difficulty faced by 
industries to obtain loans from commercial banks to embark on researches and projects execution among others. Therefore, the obstacles must be ameliorated for smooth participation of industries in the partnership Berezin et al (2018) developed infrascope index for proper assessment of the overall influence of external and internal factors in the successful implementation of innovation projects. Like many countries, Nigeria needs to learn from the submission of Berezin (2018) to develop mechanisms for attracting private investment in socially important public projects.

The $21^{\text {st }}$ century has come with changes in workplace, industries and business environment due to technological advancement. To survive and eradicate unemployment, relevant basic life skills, such as numeracy, literacy, problem solving, management, communication, negotiation and hands-on skills are inevitable in the $21^{\text {st }}$ century. These skills according to the international labour office (NISER, 2009) are required to improve confidence and capacity to explore and try new income-earning opportunities. It is however, a huge financial burden on government alone to provide the humongous training resources that will ensure the acquisition of these skills by the citizens. To address this, technical colleges have to collaborate with the private sector through publicprivate partnership. The strength of private actors in terms of innovation, technical knowledge and skills, managerial efficiency and entrepreneurial spirit among others can be combined with public actors' social responsibility cum justice, public accountability and local knowledge for delivering quality TVET through PPP (Roehrich et al, 2014)

This research therefore sought to assess public-private partnership initiative as a noble strategy of skills development and acquisition. It adoption and general roles it plays on work force development in government technical colleges in Nigeria using Lagos state as a case study. The term "public" in this study simply refers to schools or technical colleges.

This study is premised on theory of synergy of Ansoff (1987 as cited in Beneck, Schurink, \& Roodt, 2007) who believed that strategy consist of four elements; market scope, development, competitive advantage and synergy. He viewed synergy as the most important element. Argenti (as cited in Beneck, Schurink, \& Roodt, 2007) described synergy as the concept that states that the combination of two or more businesses, activities or processes will create an overall value that is greater than a sum of the individual parts. The assumption of synergy as pointed out by Ansoff (as cited in Beneck, Schurink, \& Roodt, 2007) is an increased efficiency in the sharing of skills and other assets. He categorized synergy into four namely sales, operating, investments and management synergy. 
The application of synergy theory to this study will enable the relevant stakeholders (principals, instructors and private organisations) to see their partnership as a viable synergy to get the goals technical and vocational education achieved. The synergy will also benefit the private organisations in terms of having access to relevant skilled workers and get rid of skilled mismatch affecting the employers. Beneck, Schurink, and Roodt (2007) pointed out that business unit working together will generate greater values than they would as by working apart.

\subsection{Research Design}

\section{Research Methodology}

This cross-sectional descriptive study adopted a mixed method research design combining elements of quantitative and qualitative approaches in data collection and analysis in one research. The mixed method gives a greater confidence in the convergence of findings (Teddlie \& Yu, 2007).

\subsection{Population}

The population of the study was comprised of teachers of all the five government owned technical colleges in Lagos state. This is because they are empowered by the government to interact with the private organisations via school-community relation.

\subsection{Sample and Sampling Techniques}

This study adopted a multi-stage sampling technique. Participants were divided into two strata (administrative and non-administrative staff) using stratified random sampling technique. The first stratum (administrative) comprised all the five principals and the 15 vice-principals while the second stratum (non-administrative) comprised 30 teachers, five from each school. In addition, five representatives of industries that have branches within the colleges were involved. Therefore, 55 (20 administrative, 30 non-administrative and 5 representatives of industries) participants were selected with purposive sampling method for this study.

\subsection{Instrumentation}

A self-designed 16-item questionnaire titled "Public-Private Partnership in Technical Colleges (PPPTCQ)" and a semi-structured interview were used to collect data. The questionnaire was on four scales, $0=$ Very low, $1=$ Low $2=$ Moderate $3=$ High. The questionnaire was face and content validated with the help of the experts in the field of measurement evaluation, educational management. The questionnaire's reliability was also ensured using Cronbach alpha technique and a coefficient of 0.69 was obtained. This showed the instrument was useful and consistent for the purpose for which it was prepared. 


\subsection{Data Collection}

This study made use of primary data which included questionnaire and semi-structured interview. A letter of permission was written to the principals of the selected schools before administering the instrument.

\section{Data Analysis and Interpretation}

Data gathered were statistically analyzed using frequency counts, percentage and mean rating to answer the research questions raised in the study with the aid of Statistical Package for Social Science (SPSS 22). Also, the interview result of the five representatives of the industries was qualitatively analysed

Research Question 1: What types of private bodies are in partnership with technical colleges in Lagos state on skills acquisition?

Table 4.1

Types of Private Bodies in Partnership with Technical Colleges

\begin{tabular}{clcccc}
\hline S\# & Private Body & N & Mean & SD & Rank \\
\hline 1 & Commercial Driven Org. & 50 & 3.12 & 0.435 & 1 \\
2. & Artisans Org. & 50 & 1.74 & 0.565 & 3 \\
3. & Faith-based Org. & 50 & 0.68 & 0.513 & 5 \\
4 & Philanthropic Assoc. & 50 & 2.54 & 0.503 & 2 \\
5. & Community- based org & 50 & 1.30 & 0.463 & 4 \\
\hline
\end{tabular}

Table 4.1 showed the mean rating of the various types of bodies that are in partnership with technical colleges on skills acquisition in Lagos state. From the table, it can be seen that commercial driven private entrepreneurs have the highest mean rating of 3.12. This is followed by philanthropic association with the mean score (2.54); Artisan organisations has mean score 1.74; communitybased organisations got a mean of 1.30 while faith-based organisations has a mean score 0.68. From this outcome, it could be deduced that though the presence of all the five private bodies as partners to government technical colleges is felt but commercial driven private entrepreneurs like Samsung electronics, Skippers, telecommunication companies among others are more felt because they are more of business-oriented bodies, which mostly weigh the profits they stand to see than loss. Faith-based organisations, philanthropic and community-based associations' ratings are not as high as the former because they are non-profit making organisations 
Research Question 2: What is the level of partnerships in technical colleges in Lagos State?

Table 4.2

Level of Partnerships between Technical Colleges and Private Bodies in Lagos

\begin{tabular}{clcccc}
\hline S\# & & VL (\%) & L (\%) & M (\%) & H (\%) \\
\hline 1 & $\begin{array}{l}\text { Students paid for PPP } \\
\text { service }\end{array}$ & $46(92)$ & $4(8)$ & $0(0)$ & $0(0)$ \\
2. & Staff paid for PPP & $0(0)$ & $8(16)$ & $38(76)$ & $4(8)$ \\
3. & $\begin{array}{l}\text { Retain students as } \\
\text { employees }\end{array}$ & $3(6)$ & $6(12)$ & $40(80)$ & $1(2)$ \\
4 & $\begin{array}{l}\text { Company based in the } \\
\text { school }\end{array}$ & $0(0)$ & $0(0)$ & $1(2)$ & $49(98)$ \\
5. & Total & $49(24.5)$ & $18(9)$ & $79(39.5)$ & $54(27)$ \\
\hline
\end{tabular}

Table 4.2 showed the level at which partnership takes place between technical colleges and private bodies. The table indicated that students paid for PPP service provided is low with $4(8 \%)$, while majority of the respondents rated that PPP services are provided mostly free-of-charge to students with $46(92 \%)$ very low. In addition, the table shows the level at which PPP services are provided for staff of the technical colleges, $38(76 \%)$ rated that moderately, staff are paid for the services provided while only $8(16 \%)$ said the charges are low. Furthermore, only $3(6 \%)$ rated that students are rarely retained as employees, 6 $(12 \%)$ and $40(80 \%)$ opined that the retention level as employees is very low and moderate respectively, while only $1(2 \%)$ responded that students are highly retained as employees by the private bodies that are in partnership with the technical colleges.

Lastly, It was highly rated that $49(98 \%)$ of the companies are based in the technical colleges as their branches are available in the colleges. The above analysis implies that level of PPP participation in technical colleges in Lagos is highly seen in the area of having the branches of the participating private organisations in the colleges and followed by absorbing the trained students as their workers while students only paid an insignificant for the services rendered to them. However, staff members of the colleges paid an equivalent of average of the supposed amount for the services rendered to the by private-public partnership. It is therefore deduced that there exists partnership on students' skills acquisition in technical colleges, which will make the students self-reliant and be employable by industries with relevant skills.

Research Question 3: What areas is PPP assisting in the acquisition of skills in technical colleges in Lagos state? 
Table 4.3

Areas where PPP is assisting on skills acquisition in technical colleges in Lagos

\begin{tabular}{clcccc}
\hline S\# & Areas & $\mathrm{N}$ & Mean & SD & Rank Order \\
\hline 1. & Apprenticeship & 50 & 3.46 & 0.503 & 1 \\
2. & Career Advice & 50 & 2.70 & 0.505 & 6 \\
3. & $\begin{array}{l}\text { Facilities Provision } \\
\text { \& tech development }\end{array}$ & 50 & 3.16 & 0.422 & 3 \\
4. & $\begin{array}{l}\text { Staff Time and } \\
\text { expertise }\end{array}$ & 50 & 3.30 & 0.463 & 2 \\
5. & $\begin{array}{l}\text { Business } \\
\text { Connection }\end{array}$ & 50 & 2.88 & 0.328 & 4 \\
6. & $\begin{array}{l}\text { Loan for } \\
\text { entrepreneur }\end{array}$ & 50 & 2.30 & 0.647 & 7 \\
7. & $\begin{array}{l}\text { Skills need } \\
\text { assessment }\end{array}$ & 50 & 0.405 & 0.405 & 5 \\
\hline
\end{tabular}

From table 4.3, the mean scores showed the rating of the areas in which Public-Private Partnerships is mostly assisting in the acquisition of relevant skills by the students in government technical colleges in Lagos state. Using ranking order, apprenticeship training has the highest mean score of 3.46, followed by staff time and expertise with a mean score 3.30 and facilities provision and technological development 3.16. This presupposes that private bodies involved more in the training of students and instructors professional development than other areas. Other mean ratings are business connection 2.88; skills need assessment 2.86; career advice services 2.70 and loan for entrepreneur 2.30 which is the lowest. From the analysis, it can be deduced that facilities provision, apprenticeship and staff time is the major areas of which partnership impact is mostly seen according to the respondents' opinions and experiences.

Table 4.4

List of Some Private Industries in Partnership with Technical Colleges in Lagos on Skills Acquisition and Nature of Partnership

\begin{tabular}{|c|c|c|c|c|}
\hline$S \#$ & Colleges Names & Organization & $\begin{array}{l}\text { Nature of Services } \\
\text { Provided }\end{array}$ & Beneficiaries \\
\hline 1. & $\begin{array}{l}\text { Government } \\
\text { technical college, } \\
\text { Ikotun }\end{array}$ & Skippers Nigeria & $\begin{array}{l}\text { - electrical installation and } \\
\text { training center }\end{array}$ & $\begin{array}{l}\text { students } \\
\text { teachers }\end{array}$ \\
\hline 2. & $\begin{array}{l}\text { Government } \\
\text { technical college, } \\
\text { Ikeja. }\end{array}$ & $\begin{array}{l}\text { Samsung } \\
\text { electronics }\end{array}$ & $\begin{array}{l}\text { - Provided well equipped } \\
\text { Samsung electronics } \\
\text { installation and training } \\
\text { center } \\
\text { - Provision of facilitators }\end{array}$ & $\begin{array}{l}\text { students } \\
\text { teachers } \\
\text { host community }\end{array}$ \\
\hline
\end{tabular}



3. Government technical college,
MTN foundation
- Renovation of workshops
students
Ikorodu
- Supplied training materials for electrical teachers students
- Provided power generating equipment
4. Government Julius Berger technical college, Construction on Epe.
company, Nigeria.
5. Government Eko project technical college, Ado-soba. automobile center
- donation of construction center for building and construction department
- supervision of the students during it construction
- auto repair and training workshop
students
teachers
students teachers

Source: Field work (2018)

Table 4.4 showed the imprints of some private bodies who are in partnership with government technical colleges in Lagos State on developing the skills of students and making individual student to be self-reliant during the training and after graduation.

Research Question 4: what propelled the private organisations to enter into partnership with technical colleges?

The result of the semi-structured interview of some representatives of the private organisations indicated that the partnership was ensued due to the following:

1. as part of the organization's corporate social responsibility

2. it avails the participating organisation to have access to skilled graduates and be employed

3. it enables the industries to have liaison offices located within the colleges for business purposes.

4. college teachers and staff of the industries mingle together to address skills mismatch

\section{Discussion and Conclusion}

The findings of this study on the types of private bodies in partnership with technical colleges on skills acquisition and how they are involved in the partnership indicated that commercial driven private organisations are more involved in partnership for students' skills acquisition than others with the highest mean rating. This is because they are profit-making organisations that make use of any available opportunity to advertise their product. As such, going into partnership makes it easier to achieve their business objectives. It was also found that Philanthropic organisations like rotary club, lion club were also actively involved in PPP. This disagrees with previous finding of Ayonmike, 
Igberedja, Igberaharha, and Okeke (2014) that no partnership existed between TVET institutions in Delta state and industries. This might have been as a result of research location difference.

Further findings on the level of partnerships in technical colleges in Lagos state indicated that the PPP services are provided free-of-charge to the students while staff of the colleges paid part of the cost of the services. The finding also revealed that the participating private industries also employed some of the students as their workers after training. It further revealed that most of the private bodies have their outlet within the colleges. This was done to ensure easy access for the students and staff of the colleges. This conformed with the study of Usen and Offiong (2016) on partnership for knowledge production that industries render skeletal commercial services but mostly free to students to develop skills in Nigeria.

Findings further revealed the highly rated areas where partnership is mostly helping. These include apprenticeship, career advice, facilities provision and technological development, staff time and expertise, business connection, and skills need assessment. Only the area of loan for entrepreneurs is very low. This presupposes that there is a financial challenge for the young entrepreneur to start up something after acquiring the required skills. Finally, finding also indicated that the participating industries made some profits from partnership from the services rendered to staff and some outsiders. There is need to revitalize technical and vocational education and training programme and to be able to achieve its goals of producing skillful manpower that will be self-reliant and turn the country's economy around in appositive way. This notion made publicprivate partnerships to be seen as a virile option that will take technical colleges to greater height. However, it has been discovered that this option has not been fully explored by school administrators and private bodies are also unwilling to fully participate due to some of the obnoxious policies of government on PPP. It is therefore important for government and school administrators to take away this clog in the wheel of partnership for skills acquisition.

\section{Recommendations}

Based on the findings of this study, it was recommended therefore that colleges should set up a standing committee on Public-Private Partnerships which will search for and link partners together by making each partner realizing what it stands to gain. Also, technical colleges' administrators should do more to keep in touch with industries where trainees did their Students Industrial Work Experience Scheme (SIWES). This will boost the students' chance of being employed by those industries. 
In addition, technical colleges and its coordinating agency National Board on Technical Education (NBTE) should work out modalities to always organize school-industry activities such as workshops, seminars, symposia and conferences for students and staff by writing experts from industries as resource personnel. Furthermore, government should also set up special, sectorial programmes involving enterprises, government and educational institutions to address specific situation. Lastly, business grant and start-up loan should be made available for the graduates of technical colleges by NBTE and TVET curriculum planners should fully involve private industries in the curriculum making process to ensure that trainings cover actual needs of the industry and society.

\section{References}

Aina, J. K., \& Akintunde, Z. T. (2013). Repositioning science education in Nigeria college of education through Public-private partnership (PPP). Science Journal opf Education, 5, 64-67.

Ayonmike, C. S., Igberedja, S., Igberaharha, O. C., \& Okeke, B. C. (2014). Status of partnership between TVET institutions and industries in Delta state of Niger Delta region in Nigeria. International Vocational Education and Training Association (IVETA) Annual Conference on Promoting and Sustaining Effective TVET Partnerships (pp. 1-29). Tennese, U.S.A: International Vocational Education and Training Association (IVETA).

Beneck, G., Schurink, W., \& Roodt, G. (2007). Towards a substantive theory of synergy. SA Journal of human resource management, 5(3), 9-19.

Berezin, A., Sergi, B. S., Gorodnova, N (2018). Efficiency assessment of Publicprivate partnership (PPP) projects: The case of Russia. Sustainability, 10, $1-18$.

Dunbar. (2013). Engaging the private sector in skills development. Heath and Education Advice and Resource Team (HEART). Retreived from https://www.heart-resources.org/wpcontent/uploads/2015/09/38_Private-Sector-Skills-Development.pdf

Ezenwafor, J. (2015). Rating of strategies for transforming technical and vocational education and training for the $21^{\text {st }}$ century by tertiary 
institution lecturers in south east Nigeria. International journal of educational policy research and review, 2(7), 88-97.

Igberadja, S. (2014). Challenges of Implementing Technical and Vocational Education and Training Curriculum in Nigerian universities. Global Advance Research Journal of Educational Research and Review, 3(5), 98-101.

Ijaiya, N. Y., \& Adewale, S. (2017). Challenges of facilities management in technical colleges. Journal of education in developing areas, 25(2), 536542 .

Internet geography. (2016). Location of Lagos. Retrieved August 17, 2020, from Internet geography: https://www.internetgeography.net/topics/locationof-lagos/

Japan International Cooperation Agency (JICA). (2014). Promoting Tripartite Partnerships to Tackle Skills Mismaatch: Innovative Skills Development Strategies to Accelerate Vietnam's Industrialisation. JICA.

Josh, H. (2007). Public private partnership in vocational education and training: International examples and models. Washington, DC: World Bank.

Joynes, C., Rossignoli, S., \& Fenyiwa Amonoo-Kuofi, E. (2019). $21^{\text {st }}$ Century Skills: Evidence of issues in definition, demand and delivery for development context (K4D Helpdesk Report). Brighton, UK: Institute of Development Studies.

Maigida, F. (2014). Building and sustaining partnerships through public private partnership for effective technical and vocational education and training in Nigeria. International Vocational Education Association (IVETA). Nashville,USA: International Vocational Education Association (IVETA).

Mbah, C., Obi, C. U., Ehimen, T. E., \& Onyebuenyi, P. N. (2018). Improving school-industry partnership in skills development of TVET students for matching skill demand in Anambra state. Improving TVET quality for matching skills demand and supply (pp. 1-1). Nsuka: National Conference of Centre for Technical and Vocational Education, Training and Research. 
McQuaid, R. W. (2000). The theory of partnership: why have partnerships. Retrieved July 29, 2020, from https://www.researchgate.net: https://www.researchgate.net

NBS. (2020, August 14). Nigeria unemployment rate rises to 27.1\%. The Punch.

Nigerian Institute of Social and Economic Research (NISER). (2009). Study on skills development for the informal sector of the Nigerian economy. Ibadan: NISER/World Bank.

OECD. (2013). Enhancing skills through Public-private partnership in Kazakhstan's information technology sector. Kazakhstan: OECD.

Okpor, I., \& Hassan, N. (2012). Public-Private Partnership for Skills Acquisition and Vocational Technical Education Development in Nigeria. Mediterranean Journal of Social Sciences, 3(4), 91-94.

Olabiyi, O. S., Okafor, B. O., \& Bamidele, O. E. (2014). Facilities improvement through public-private partnership for enhancing foundation skills among technical vocational education students in Nigeria. Enviromental and Natural Resource Research, 4(2), 11-19.

Roehrich, J. K., Lewis, M. A., \& George, G. (2014). Are public-private partnership a healthy option? A systematic literature review. Social Science \& Medicine, 113, 110-119. doi:10.101/J.soc.Scimed2014.03.037

Suriana, B. (2012). Strategy to revitalise Technical and Vocational Education and Training (TVET): Management perspective. Global Journal of Management and Business Research, 12(23), 1-5.

Teddlie, C., \& Yu, F. (2007). Mixed method sampling: a typology with examples. Journal of mixed method research, 1(1), 77-100.

UNESCO. (2002). Technical and vocational education and training for the twenty-first century. Paris: UNESCO.

Usen, S. M., \& Offiong, A. A. (2016). Partnership for knowledge production: a panacea for skills acquisition for sustainable development through vocational education in Nigeria. International journal of vocational and technical education research, 2(3), 19-24. 
International Journal of Innovation in Teaching and Learning (IJITL)

Volume VII- Issue II (December 2021)

\section{Citation of this Article:}

Adewale, S. (2021). Assessment of Public-Private Partnership in Technical Colleges in Nigeria: A Case of Lagos State. International Journal of Innovation in Teaching and Learning (IJITL), 7(2), 36-51. 